Article

\title{
Morphological Identification of Lepidii Seu Descurainiae Semen and Adulterant Seeds Using Microscopic Analysis
}

\author{
Jun-Ho Song $₫$, Byeong Cheol Moon $₫$, Goya Choi and Sungyu Yang * \\ Herbal Medicine Resources Research Center, Korea Institute of Oriental Medicine, Naju 58245, Korea; \\ songjh@kiom.re.kr (J.-H.S.); bcmoon@kiom.re.kr (B.C.M.); serparas@kiom.re.kr (G.C.) \\ * Correspondence: sgyang81@kiom.re.kr; Tel.: +82-61-338-7114
}

Received: 21 September 2018; Accepted: 31 October 2018; Published: 2 November 2018

\begin{abstract}
Lepidii seu Descurainiae Semen, the dried ripe seeds of Descurainia sophia (L.) Webb ex Prantl or Lepidium apetalum Willd., is used widely as a traditional herbal medicine in Northeast Asia. However, seeds of a number of other species have been misidentified as Lepidii seu Descurainiae Semen, and are therefore misused because of morphological similarities among the seeds of these species. To accurately identify Lepidii seu Descurainiae Semen, we investigated the morphology, mucilage reaction, and micromorphology of Lepidii seu Descurainiae Semen and the seeds of other plant species. We used a stereomicroscope and a scanning electron microscope to describe and compare various morphological and micromorphological characteristics of seeds, and a light microscope to determine the presence or absence of mucilage. We evaluated the potential usefulness of mucilage as a morphological marker for seed identification. The shape, outline, and size of seeds were useful characteristics for identification. The mucilage reaction and the three types of seed ornamentation that were identified in this study were particularly valuable for seed authentication. Based on these results, we created an identification key based on morphology and micromorphology of Lepidii seu Descurainiae Semen and adulterant seeds. The method of seed identification using microscopic examination, as described here, is easy and economical, making it a potential key tool for accurate identification of Lepidii seu Descurainiae Semen and seeds of other medicinal plants.
\end{abstract}

Keywords: Descurainia sophia (L.) Webb ex Prantl; Lepidii seu Descurainiae Semen; Lepidium apetalum Willd.; morphological identification key; mucilage; scanning electron microscope

\section{Introduction}

According to the Korean Herbal Pharmacopoeia [1,2], Lepidii seu Descurainiae Semen refers to the dried ripe seeds of Descurainia sophia (L.) Webb ex Prantl or Lepidium apetalum Willd., which belongs to the family Brassicaceae (Cruciferae). Lepidii seu Descurainiae Semen is used in Northeast Asian countries, including Korea, China, and Taiwan, as an herbal medicine, called "Jeong-Ryeok-Ja" in Korean and "Ting-Li-Zi" in Chinese.

Although the Pharmacopoeia of the People's Republic of China and the Taiwan Herbal Pharmacopoeia have designated the seeds of De. sophia or L. apetalum as Descurainiae Semen (southern lepidium) or Lepidii Semen (northern lepidium), respectively, seeds of both plant species are sources of the same herbal medicine [1,3-5]. In Korea, prior to the revision of the Korean Herbal Pharmacopoeia (KHP) in 2013, the herbal medicine Jeong-Ryeok-Ja was believed to be derived from the seeds of Draba nemorosa L. and L. apetalum as Semen Drabae et Lepidii [2,6]. Seeds of Dr. nemorosa and L. apetalum are currently designated as sources of the same herbal medicine in the Pharmacopoeia of Democratic People's Republic of Korea [1,7]. 
Traditionally, Lepidii seu Descurainiae Semen has been used as a demulcent, laxative, and an aperient drug [8]. Studies have shown that this herbal medicine has anti-inflammatory, analgesic, antipyretic, anticancer, and antioxidant properties. It is also used to treat functional constipation [9-12]. However, a number of misuse issues have emerged due to the inaccurate identification of seeds of other plant species as Lepidii seu Descurainiae Semen $[2,13,14]$. For example, seeds of Dr. nemorosa, defined in the unrevised KHP before 2013, are currently sold in herbal markets as Lepidii seu Descurainiae Semen. Similarly, seeds of Erysimum cheiranthoides L. and Erysimum macilentum Bunge (family Brassicaceae) are often found as adulterants in Lepidii seu Descurainiae Semen because of the morphological similarities among these species. The plant species L. apetalum is strictly distributed in the northern part of the Korean peninsula; however, Lepidium virginicum L., a close relative of L. apetalum, is found in all provinces of Korea. Therefore, it is likely to replace L. apetalum. The National Institute of Food and Drug Safety Evaluation has alerted consumers to discriminate between authentic and inauthentic Lepidii seu Descurainiae Semen [15]. Morphological analysis [2] and molecular studies [16] have been conducted to facilitate the accurate identification and authentication of original plant species with morphological similar species. However, the identification of minute seed medicines based on morphological characteristics has not been investigated.

It is important to accurately identify minute seed medicines. However, the seeds are difficult to distinguish by the naked eye. Therefore, studies using stereomicroscopes have been conducted to facilitate morphological identification of these seeds $[17,18]$. A macroscopic authentication study of Chinese materia medica seeds and fruits in the United Kingdom (U.K.) market was carried out to guide quality control of herbal medicine [19]. Production of mucilage by distinguished epidermal cells during hydration (myxocarpy) has been observed by light microscopy [20]. The presence or absence of a mucilage reaction is a useful diagnostic characteristic for the taxonomic identification of plant species [20-27]. Investigation of the micromorphological characteristics of seeds using a scanning electron microscope has been used to identify and distinguish species [28-34]. Thus, these techniques can be used to authenticate and distinguish genuine species from close relatives, inferior substitutes, adulterants, and counterfeits.

The present study conducted microscopic investigations and aimed to describe and illustrate the morphology, micromorphology, and mucilage reaction of Lepidii seu Descurainiae Semen, along with those of seeds of close relatives and adulterants. Based on the results, we created morphological and micromorphological identification keys that can be used to authenticate minute seeds.

\section{Materials and Methods}

\subsection{Plant Materials}

Two authentic plant species (De. sophia and L. apetalum) and four adulterant species (Dr. nemorosa, E. cheiranthoides, E. macilentum, and L. virginicum) were collected from natural populations in Korea and China during the fruiting season (April 2016 to May 2017). The morphological characteristics of mature seeds of these species were used for analysis. To confirm the consistency of the morphological characteristics, at least two samples of each species were collected from different sites and compared. All of the seed samples were deposited in the Korean Herbarium of Standard Herbal Resources (Index Herbariorum code KIOM) at the Korea Institute of Oriental Medicine, Daejeon, Korea. Detailed information about plant materials used in this study, including the collection sites, collection dates, and the voucher number of plant specimens deposited in KIOM, is summarized in Table 1. 
Table 1. List of plant species used in this study along with the collection site, collection date, and voucher number.

\begin{tabular}{|c|c|c|c|}
\hline Scientific Name & Collection Site & Collection Date & Voucher No. \\
\hline \multirow{4}{*}{ Descurainia sophia (L.) Webb ex Prantl * } & Pyeongtaek, Gyeonggi, Korea & 11 May 2016 & MBC_KIOM-2016-049 \\
\hline & Muju, Jeonbuk, Korea & 31 May 2016 & MBC_KIOM-2016-072 \\
\hline & Gurye, Jeonnam, Korea & 2 June 2016 & KWJ_KIOM-2016-025 \\
\hline & Danyang, Chungbuk, Korea & 23 May 2017 & MBC_KIOM-2017-029 \\
\hline Lepidium apetalum Willd. * & Antu, Yanbian, Jilin, China & 30 June 2016 & MBC_KIOM-2016-088 \\
\hline \multirow{3}{*}{ Draba nemorosa L. ${ }^{\dagger}$} & Anseong, Gyeonggi, Korea & 12 May 2017 & MBC_KIOM-2016-057 \\
\hline & Hapcheon, Gyeongnam, Korea & 7 May 2017 & MBC_KIOM-2016-029 \\
\hline & Yuseong, Daejeon, Korea & 19 April 2016 & CGY_KIOM-2016-2 \\
\hline \multirow{2}{*}{ Erysimum cheiranthoides L. ${ }^{\dagger}$} & Danyang, Chungbuk, Korea & 15 July 2016 & KIOM201601017294 \\
\hline & Danyang, Chungbuk, Korea & 28 July 2016 & MBC_KIOM-2016-228 \\
\hline \multirow{2}{*}{ Erysimum macilentum Bunge ${ }^{+}$} & Gurye, Jeonnam, Korea & 10 May 2016 & MBC_KIOM-2016-040 \\
\hline & Andong, Gyeongbuk, Korea & 25 May 2016 & CGY_KIOM-2016-008 \\
\hline \multirow{3}{*}{ Lepidium virginicum $\mathrm{L}^{+}$} & Sancheong, Gyeongnam, Korea & 6 May 2016 & MBC_KIOM-2016-027 \\
\hline & Buan, Jeonbuk, Korea & 1 June 2016 & MBC_KIOM-2016-075 \\
\hline & Anseong, Gyeonggi, Korea & 12 May 2016 & MBC_KIOM-2016-059 \\
\hline
\end{tabular}

* Official plant species designated as sources of Lepidii seu Descurainiae Semen in the current Korean Herbal Pharmacopoeia and Pharmacopoeia of the People's Republic of China. ${ }^{\dagger}$ These plant species do not have an appropriate herbal name in the current Korean Herbal Pharmacopoeia and Pharmacopoeia of the People's Republic of China.

\subsection{External Morphology}

Measurements and optical observations of 20 seeds for each of the 15 collection sites (voucher) for a total of 300 seeds were recorded. A digital Vernier caliper (CD-15CP, Mitutoyo, Kawasaki, Japan) was used to measure the length, width, and length/width ratio. The general shape $(\times 2$ magnification), cross-sectional shape $(\times 8$ magnification), and color were recorded using a stereomicroscope (Olympus SZX16, Olympus, Tokyo, Japan) (Table 2). Cross-sections of seeds were prepared by cutting them down the middle part using a single-edge blade (DN-52, Dorco, Seoul, Korea). The hilum part was placed at the bottom, and images were captured while using a digital camera (Olympus DP21, Olympus, Tokyo, Japan). The weight of 1000 randomly selected seeds (1000-seed weight) was measured (in six replicates) using an electronic precision balance (PS 1000.R1, RADWAG Balances \& Scales, Radom, Poland).

Table 2. Morphological characteristics of Descurainia sophia and Lepidium apetalum (authentic sources of Lepidii seu Descurainiae Semen) and adulterant species.

\begin{tabular}{|c|c|c|c|c|c|c|c|c|}
\hline $\begin{array}{l}\text { Scientific } \\
\text { Name }\end{array}$ & Shape & $\begin{array}{c}\text { Cross-Sectional } \\
\text { Shape }\end{array}$ & $\mathbf{W A}^{\mathrm{a}}$ & Color $^{b}$ & $\begin{array}{l}\text { Average } \\
\text { Length } \\
(\mathrm{mm})\end{array}$ & $\begin{array}{l}\text { Average } \\
\text { Width } \\
(\mathrm{mm})\end{array}$ & $\begin{array}{l}\text { Average } \\
\text { 1000-Seed } \\
\text { Weight (g) }\end{array}$ & MR $^{c}$ \\
\hline $\begin{array}{l}\text { Descurainia } \\
\text { sophia }\end{array}$ & Oblong & Circular-to-elliptic & Absent & $\begin{array}{l}\mathrm{Br} \text { to } \\
\mathrm{RBr} / \mathrm{S}\end{array}$ & 1.14 & 0.60 & 0.155 & + \\
\hline $\begin{array}{l}\text { Lepidium } \\
\text { apetalum }\end{array}$ & $\begin{array}{c}\text { Ovoid, } \\
\text { obovate-to-oblong }\end{array}$ & $\begin{array}{l}\text { Linear-elliptic to } \\
\text { linear-triangular }\end{array}$ & $\begin{array}{l}\text { Absent or } \\
\text { narrow }\end{array}$ & $\begin{array}{c}\mathrm{Br} \text { to } \\
\mathrm{RBr} / \mathrm{D}\end{array}$ & 1.49 & 0.84 & 0.224 & ++ \\
\hline Draba nemorosa & Oblong-to-ovoid & Linear-elliptic & Absent & $\begin{array}{c}\mathrm{Br} \text { to } \\
\mathrm{RBr} / \mathrm{D}\end{array}$ & 0.71 & 0.44 & 0.035 & - \\
\hline $\begin{array}{c}\text { Erysimum } \\
\text { cheiranthoides }\end{array}$ & $\begin{array}{c}\text { Obliquely } \\
\text { oblong-to-obovate, } \\
\text { pyriform }\end{array}$ & Circular or ovate & Absent & $\begin{array}{l}\mathrm{PBr} \text { to } \\
\mathrm{RBr} / \mathrm{S}\end{array}$ & 1.35 & 0.62 & 0.165 & - \\
\hline $\begin{array}{l}\text { Erysimum } \\
\text { macilentum }\end{array}$ & Oblong & $\begin{array}{l}\text { Triangular-to- } \\
\text { trapezoid }\end{array}$ & Absent & $\begin{array}{l}\mathrm{PBr} \text { to } \\
\mathrm{RBr} / \mathrm{S}\end{array}$ & 1.01 & 0.50 & 0.106 & - \\
\hline $\begin{array}{l}\text { Lepidium } \\
\text { virginicum }\end{array}$ & $\begin{array}{c}\text { Ovoid, } \\
\text { obovate-to-oblong }\end{array}$ & $\begin{array}{l}\text { Linear-elliptic to } \\
\text { linear-triangular }\end{array}$ & Wide & $\begin{array}{l}\mathrm{Br} \text { to } \\
\mathrm{RBr} / \mathrm{D}\end{array}$ & 1.98 & 1.19 & 0.413 & ++ \\
\hline
\end{tabular}

${ }^{a}$ WA, wing-like appendage. ${ }^{b} \mathrm{Br}$, brown; $\mathrm{PBr}$, pale brown; $\mathrm{RBr}$, reddish brown; D, dull; $\mathrm{S}$, shiny. ${ }^{\mathrm{c}} \mathrm{MR}$, mucilage reaction; -, no reaction; +, weak reaction; ++, moderate reaction. 


\subsection{Statistical Analyses}

To demonstrate variations in seed length and width among species, box plots were created using the ggplot2 library in R [35].

\subsection{Mucilage Reaction}

Five mature and healthy seeds of each collection site and a total of 15 samples, 75 seeds were treated with distilled water and examined under a light microscope (Olympus BX-53, Olympus, Tokyo, Japan). The degree of mucilage reaction was classified as absent, weak (0.1-0.5 mm), or moderate $(>0.5 \mathrm{~mm})$ [20], and images of the mucilage reaction were captured using a digital camera (Olympus DP21, Olympus, Tokyo, Japan).

\subsection{Micromorphology}

To examine the seed coat or testa, selected seeds were mounted directly on aluminum stubs using double-side adhesive carbon tape. Stubs were coated with gold using a sputter coater (208HR, Cressington Scientific Instruments Ltd., Watford, UK), and testa were observed using a low voltage field emission scanning electron microscope (JSM-7000F, JEOL, Tokyo, Japan) at an accelerating voltage of $5 \mathrm{kV}$ with a working distance of $9-10 \mathrm{~mm}$. The micromorphological terminology used to describe the seeds that was used in this study followed that of Barthlott [29] and Song et al. [34].

\section{Results}

\subsection{Morphological Characteristics of Seeds}

Lepidii seu Descurainiae Semen is the seeds of De. sophia or L. apetalum. Seeds of De. sophia were oblong in shape, circular-to-elliptic in cross-section, with one or two shallow ventral grooves and a concave hilum (Figures $1 \mathrm{~A}$ and $2 \mathrm{~A}$ ). The testa was brown-to-reddish brown and slightly shiny, and the wing-like appendage was absent. Seeds of De. sophia ranged from $0.98-1.32 \mathrm{~mm}$ in length and $0.48-0.70 \mathrm{~mm}$ in width. The length:width ratio and 1000-seed weight varied from 1.56 to 2.71 and 0.140 to $0.170 \mathrm{~g}$, respectively.

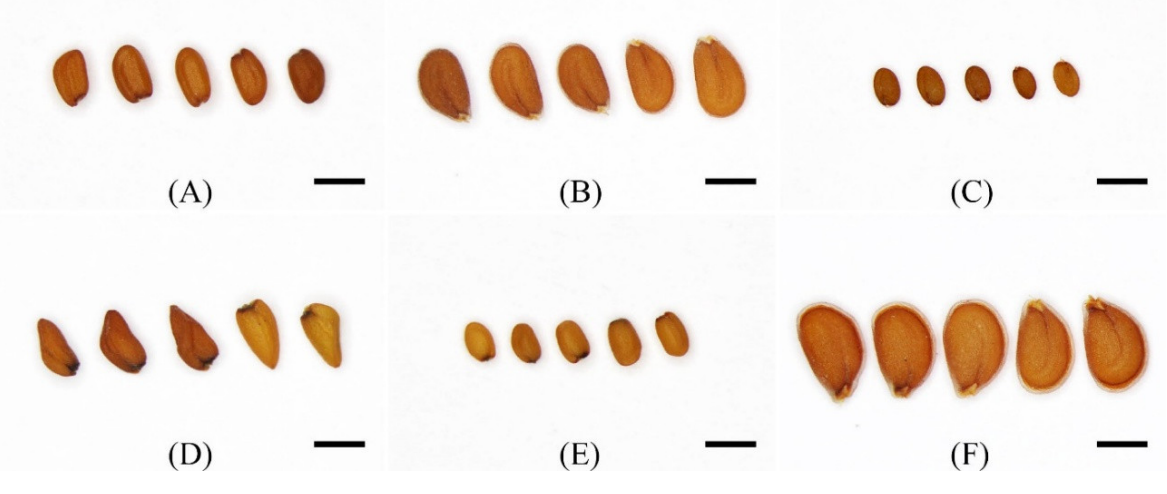

Figure 1. Stereomicroscope micrographs showing the seed morphology of six plant species.

(A) Descurainia sophia; (B) Lepidium apetalum; (C) Draba nemorosa; (D) Erysimum cheiranthoides;

(E) Erysimum macilentum; and (F) Lepidium virginicum. Scale bars $=1 \mathrm{~mm}$.

In contrast, seeds of L. apetalum were ovoid, obovate-to-oblong in shape, and linear-elliptic to linear-triangular in cross-section (Figures 1B and 2B). Seeds possessed two grooves on both dorsal and ventral surfaces, although one groove was more prominent than the other. The hilum was concave. The testa was dull, brown-to-reddish brown, and the wing-like appendage was narrow or almost absent. Seeds of L. apetalum varied from 1.25 to $1.67 \mathrm{~mm}$ in length and 0.56 to $1.00 \mathrm{~mm}$ in 
width. The length:width ratio of seeds ranged from 1.28 to 2.55 and the 1000 -seed weight varied from $0.210-0.235 \mathrm{~g}$.

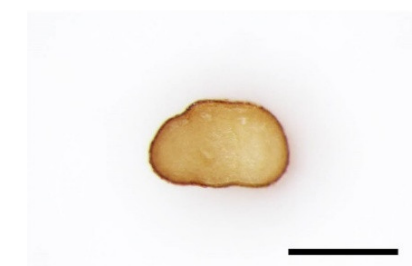

(A)

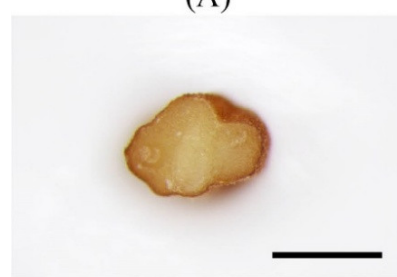

(D)

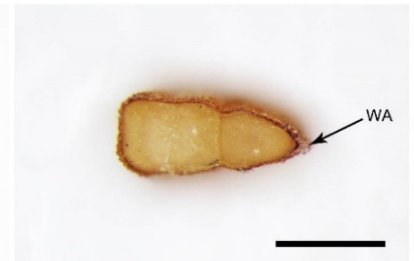

(B)

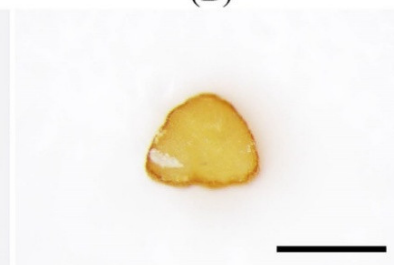

(E)

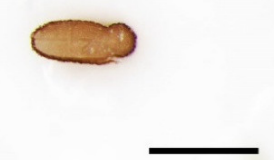

(C)

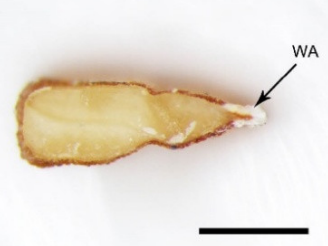

(F)

Figure 2. Stereomicroscope micrographs showing the cross-sectional shape of seeds. (A) Descurainia Sophia; (B) Lepidium apetalum; (C) Draba nemorosa; (D) Erysimum cheiranthoides; (E) Erysimum macilentum; and (F) Lepidium virginicum. WA: Wing-like appendage. Scale bars $=0.5 \mathrm{~mm}$.

Dr. nemorosa is excluded from the current KHP. Seeds of Dr. nemorosa, Drabae Semen, are adulterants in Lepidii seu Descurainiae Semen. Drabae Semen was oblong-to-ovoid in shape, flat, and linear-elliptic in cross-section, with one shallow groove on the ventral surface (Figures $1 \mathrm{C}$ and $2 \mathrm{C}$ ). The hilum was concave and globose. The testa was dull, brown-to-reddish brown, and it lacked the wing-like appendage. Seeds were $0.57-0.86 \mathrm{~mm}$ long and $0.33-0.55 \mathrm{~mm}$ wide, with a length:width ratio of 1.17-2.41 and 1000-seed weight of $0.030-0.040 \mathrm{~g}$. Seeds of Dr. nemorosa were distinguishable from those of other species based on their relatively small size (average: $0.71 \times 0.44 \mathrm{~mm}$; Table 2 and Figure 3) and cross-sectional in shape.

Seeds of E. cheiranthoides and E. macilentum are adulterants in Lepidii seu Descurainiae Semen because of their morphological similarities. Seeds of E. cheiranthoides were frequently twisted, obliquely oblong-to-obovate and pyriform in shape, and circular or ovate in cross-section, with a convex ventral surface (Figures 1D and 2D). The hilum was concave and almost black. The testa was slightly shiny and pale brown-to-reddish brown, without a wing-like appendage. Seeds were 1.13-1.52 mm long and $0.51-0.75 \mathrm{~mm}$ wide, with a length:width ratio ranging from 1.61 to 2.64 and 1000 -seed weight ranging from 0.150 to $0.176 \mathrm{~g}$. In contrast, seeds of E. macilentum were oblong. They were triangular-to-trapezoid in cross-section, with a slightly convex ventral surface. These seeds exhibited a concave hilum, with a slightly shiny and a pale brown-to-reddish brown testa; no wing-like appendage was visible (Figures 1E and 2E). Seeds measured $0.67-1.19 \mathrm{~mm}$ in length and $0.38-0.64 \mathrm{~mm}$ in width, with a length:width ratio of 1.21-2.53 and 1000-seed weight of 0.095-0.110 g. Seeds of E. cheiranthoides and E. macilentum were distinguishable from those of others that were based on their shape and cross-section, respectively.

L. virginicum is a close relative of L. apetalum. Seeds of L. virginicum, which are adulterants in Lepidii seu Descurainiae Semen, were ovoid, obovate-to-oblong in shape, and linear-elliptic to linear-triangular in cross-section, with one groove on both surfaces (Figures $1 \mathrm{~F}$ and $2 \mathrm{~F}$ ). The hilum of $L$. virginicum seeds was concave, and the testa was dull and brown-to-reddish brown. These seeds possessed a clearly distinct wing-like appendage. The length and width of these seeds varied from 1.65 to $2.21 \mathrm{~mm}$ and 0.92 to $1.48 \mathrm{~mm}$, respectively. Their length:width ratio and 1000-seed weight varied from 1.34 to 2.12 and 0.398 to $0.435 \mathrm{~g}$, respectively. Although the seeds of L. virginicum were morphologically similar to those of L. apetalum in terms of shape, cross-sectional shape, and color, L. virginicum seeds were approximately 1.3 -fold larger than L. apetalum seeds (Figure 3 ) and they exhibited a well-developed wing-like appendage, unlike L. apetalum seeds. 


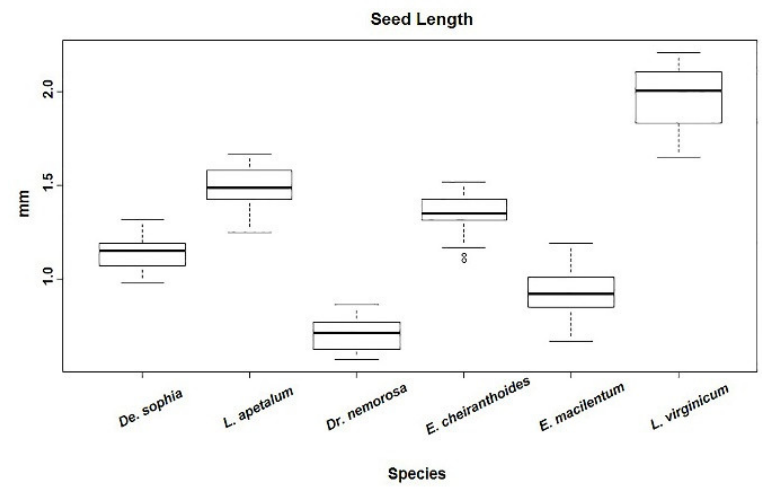

(A)

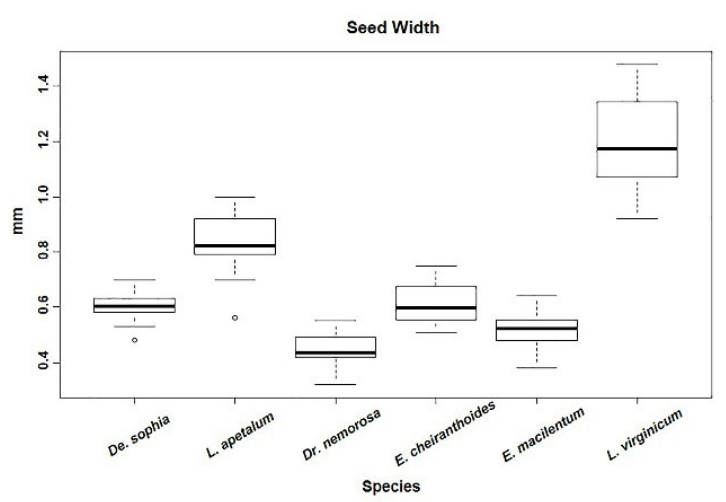

(B)

Figure 3. The size of Lepidii seu Descurainiae Semen and that of the seeds of related species: (A) seed length and (B) seed width. Box plots show the median, 25th, and 75th percentiles (box), 10th and 90th percentiles (whiskers), and outliers (open circle).

\subsection{Mucilage Reaction}

The mucilage present on the seed coat reacts with water and release. Thus, a positive mucilage reaction can be observed in seeds that produce mucilage. We treated the seeds of all six species with distilled water and characterized the mucilage reaction. A weak mucilage reaction was observed in the seeds of De. sophia $(0.05-0.1 \mathrm{~mm}$; Figure $4 \mathrm{~A}, \mathrm{G})$, whereas a moderate reaction $(0.2-0.4 \mathrm{~mm})$ was observed in seeds of L. apetalum (Figure 4B,H) and L. virginicum (Figure 4F,I). In contrast, seeds of Dr. nemorosa (Figure 4C), E. cheiranthoides (Figure 4D), and E. macilentum (Figure 4E) showed no mucilage reaction. Moreover, these patterns were consistently observed at the species level; different sites of the same species had no variation.

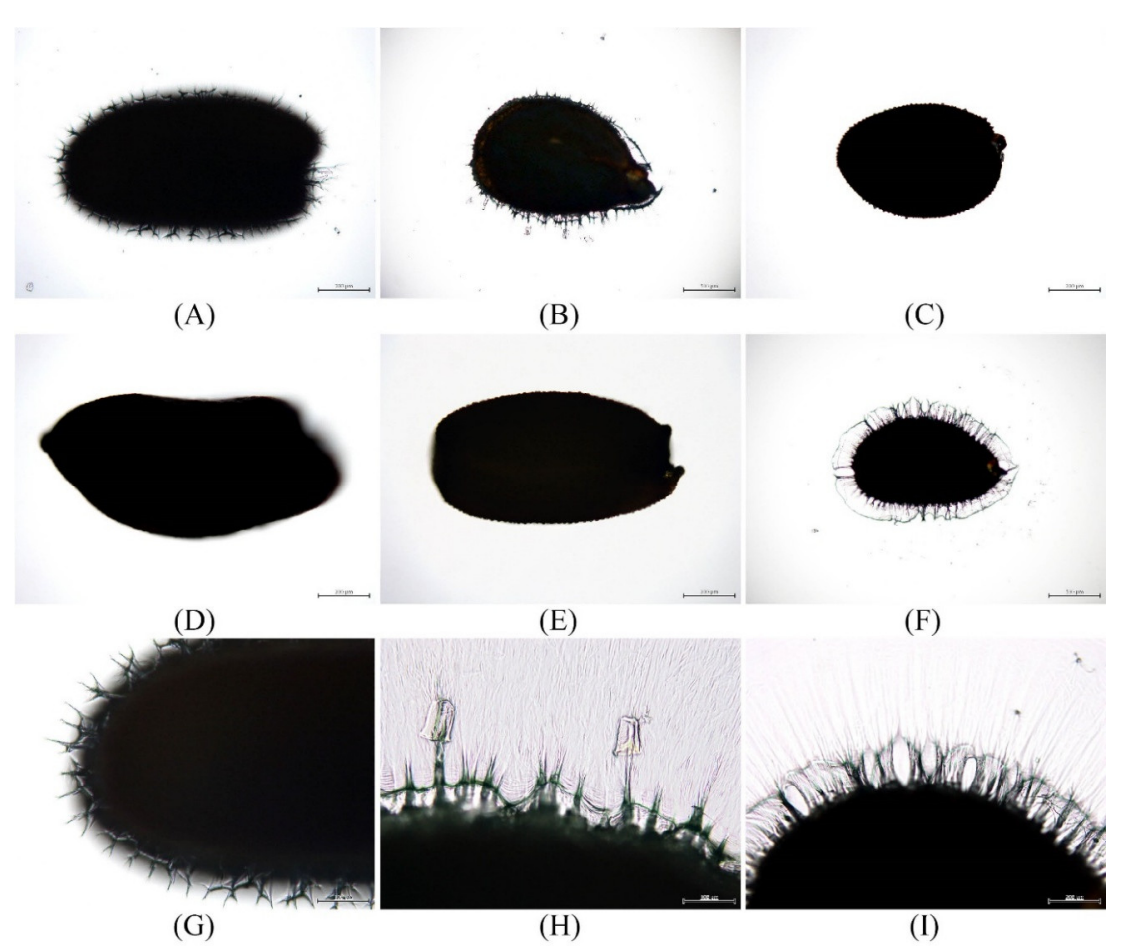

Figure 4. Light microscope micrographs showing release of mucilage from seeds upon hydration. (A,G) Descurainia sophia; weak mucilage reaction. (B,H) Lepidium apetalum; moderate mucilage reaction. (C) Draba nemorosa; no mucilage reaction. (D) Erysimum cheiranthoides; no mucilage reaction. (E) Erysimum macilentum; no mucilage reaction. (F,I) Lepidium virginicum; moderate mucilage reaction. 


\subsection{Micromorphological Characteristics}

Examination of seeds using a scanning electron microscope revealed remarkable variation in surface patterns (Table 3 and Figure 5). We categorized seeds into three major types (Types I, II, and III) based on their ornamentation, epidermal cell pattern, and the shape of the anticlinal and periclinal cell walls. Each type was further categorized into two subtypes. The epidermal cell shape was irregular, rounded, isodiametric, or tetra-to-polygonal. The boundary of the anticlinal cell wall was almost indistinct in some seeds, but it was raised in others. Anticlinal cell walls were straight or slightly sinuous, thick or thin, and with a surface that was either smooth or possessed fine folds or coarse folded papillae. Periclinal cell walls showed a large variation among species, ranging from concave to strongly convex, with a surface that was either smooth with globular central tuberculae or coarse with folded central papillae.

Table 3. Micromorphological characteristics of Descurainia sophia and Lepidium apetalum (authentic sources of Lepidii seu Descurainiae Semen) and adulterant species.

\begin{tabular}{|c|c|c|c|c|}
\hline Scientific Name & Ornamentation (Type) & $\begin{array}{l}\text { Epidermal Cell } \\
\text { Pattern }\end{array}$ & Anticlinal Cell Wall & Periclinal Cell Wall \\
\hline Descurainia sophia & Simple reticulate (I-1) & $\begin{array}{l}\text { Irregular, } \\
\text { rounded-to-polygonal }\end{array}$ & $\begin{array}{l}\text { Raised, straight to slightly } \\
\text { sinuous, thick, } \\
\text { smooth-to-fine folds }\end{array}$ & Concave, smooth \\
\hline Lepidium apetalum & Reticulate-papillate (III-1) & $\begin{array}{l}\text { Isodiametric, } \\
\text { polygonal }\end{array}$ & $\begin{array}{l}\text { Nearly indistinct, straight, } \\
\text { thin, smooth-to-fine folds }\end{array}$ & $\begin{array}{l}\text { Convex, coarse folded } \\
\text { narrow central papillae, } \\
\text { radiate-striate }\end{array}$ \\
\hline Draba nemorosa & Simple reticulate (I-2) & $\begin{array}{l}\text { Isodiametric, } \\
\text { tetra-to-hexagonal }\end{array}$ & $\begin{array}{l}\text { Raised, straight, thick, } \\
\text { smooth or coarse folded } \\
\text { papillae }\end{array}$ & Concave, smooth \\
\hline $\begin{array}{l}\text { Erysimum } \\
\text { cheiranthoides }\end{array}$ & Reticulate-tuberculate (II-1) & $\begin{array}{c}\text { Isodiametric, } \\
\text { penta-to-hexagonal }\end{array}$ & $\begin{array}{l}\text { Slightly raised, straight, } \\
\text { thick, smooth-to-fine folds }\end{array}$ & $\begin{array}{c}\text { Convex, globular narrow } \\
\text { central tuberculae, } \\
\text { radiate-striate }\end{array}$ \\
\hline $\begin{array}{l}\text { Erysimum } \\
\text { macilentum }\end{array}$ & Reticulate-tuberculate (II-2) & $\begin{array}{l}\text { Isodiametric, } \\
\text { tetra-to-hexagonal }\end{array}$ & $\begin{array}{l}\text { Raised, straight, thick, } \\
\text { smooth-to-fine folds }\end{array}$ & $\begin{array}{c}\text { Strongly convex, globular } \\
\text { wide central tuberculae, } \\
\text { radiate-striate }\end{array}$ \\
\hline Lepidium virginicum & Reticulate-papillate (III-2) & $\begin{array}{l}\text { Isodiametric, } \\
\text { polygonal }\end{array}$ & $\begin{array}{l}\text { Slightly raised, straight, } \\
\text { thin, smooth-to-fine folds }\end{array}$ & $\begin{array}{l}\text { Strongly convex, coarse } \\
\text { folded wide central } \\
\text { papillae, radiate-striate }\end{array}$ \\
\hline
\end{tabular}

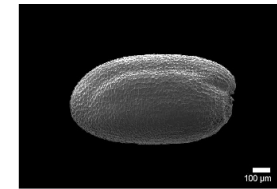

(A)
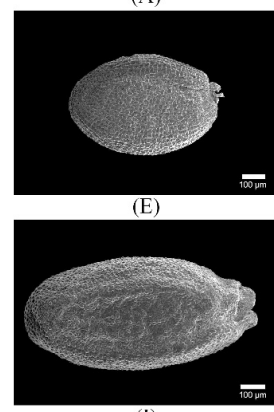

(I)

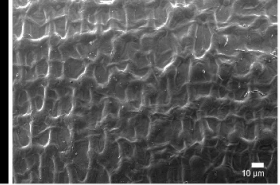

(B)
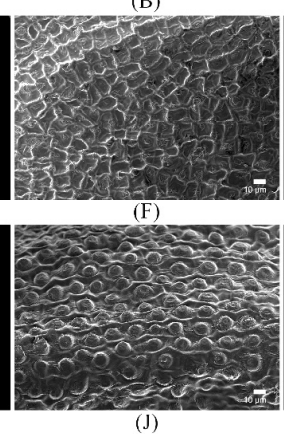
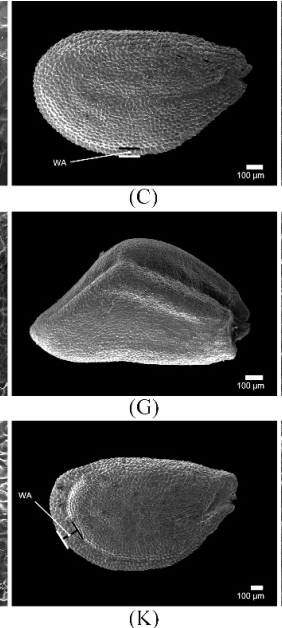

(C)
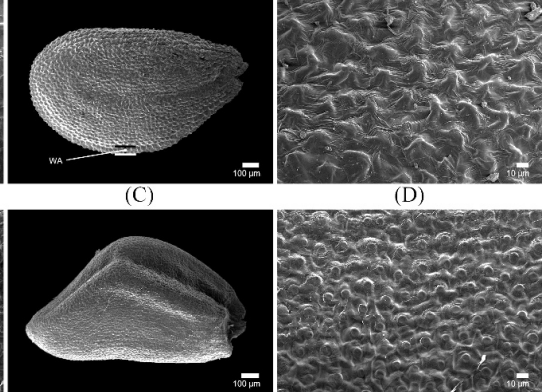

(H)

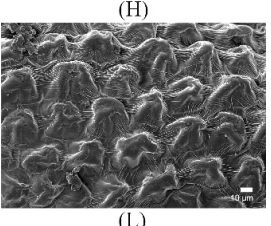

(L)

Figure 5. Scanning electron microscope micrographs showing $(\mathbf{A}, \mathbf{C}, \mathbf{E}, \mathbf{G}, \mathbf{I}, \mathbf{K})$ an overview of the seed surface and (B,D,F,H,J,L) detailed seed ornamentation. (A,B) Descurainia sophia (Type I-1; simple reticulate); (C,D) Lepidium apetalum (Type III-1; reticulate-papillate); (E,F) Draba nemorosa (Type I-2; simple reticulate); (G,H) Erysimum cheiranthoides (Type II-1; reticulate-tuberculate); (I,J) Erysimum macilentum (Type II-2; reticulate-tuberculate); (K,L) Lepidium virginicum (Type III-1; reticulate-papillate). WA: wing-like appendage. 
Type I seeds included those of De. sophia and Dr. nemorosa. These seeds showed simple reticulate ornamentation with a raised, thick anticlinal cell wall and a concave, smooth periclinal cell wall (Figure 5A,B,E,F). The reticulate ornamentation of Type I seeds was divided into two subtypes (Type I-1 and Type I-2), based on the epidermal cell pattern and anticlinal cell wall surface. Seeds of De. sophia were designated as Type I-1 and they showed an irregular, rounded, or polygonal epidermal cell pattern; the surface of the anticlinal wall was either smooth or had fine folds (Figure 5B). Seeds of Dr. nemorosa were categorized as Type I-2, with an isodiametric or tetra-to-hexagonal epidermal cell pattern; the surface of the anticlinal wall was either smooth or coarse with folded papillae (Figure 5F).

Type II seeds included those of E. cheiranthoides and E. macilentum. These seeds showed reticulate-tuberculate ornamentation, with a straight, thick, smooth-to-fine folded anticlinal cell wall and a convex, radiate-striate periclinal cell wall with globular central tuberculae (Figure 5G-J). The reticulate-tuberculate ornamentation of Type II seeds was further divided into two subtypes (Type II-1 and Type II-2), which were based on the degree of anticlinal cell wall and the diameter of the tuberculae. E. cheiranthoides seeds were designated as Type II-1; these possessed a slightly raised anticlinal cell wall and a convex periclinal cell wall with narrow tuberculae $(5.0-9.2 \mu \mathrm{m}$ in diameter; average $=6.9 \mu \mathrm{m})$ (Figure $5 \mathrm{H}$ ). Seeds of E. macilentum were categorized as Type II-2; these seeds exhibited a raised anticlinal cell wall and a strongly convex periclinal cell wall with wide tuberculae $(9.1-17.2 \mu \mathrm{m}$ in diameter; average $=12.4 \mu \mathrm{m})$ (Figure 5J).

Type III seeds included those of L. apetalum and L. virginicum. These seeds showed reticulatepapillate ornamentation with an isodiametric or polygonal epidermal cell pattern. The anticlinal wall was straight and thin, with a smooth or finely folded surface, and the periclinal cell wall was radiate-striate with coarse folded central papillae (Figure $5 \mathrm{C}, \mathrm{D}, \mathrm{K}, \mathrm{L}$ ). The reticulate-papillate ornamentation of Type III seeds was divided into two subtypes (Type III-1 and Type III-2), based on the degree of anticlinal cell wall and the diameter of papillae. Type III-1 seeds were observed in L. apetalum; these showed a nearly indistinct anticlinal cell wall and a convex periclinal cell wall with narrow papillae $(9.4-16.0 \mu \mathrm{m}$ in diameter; average $=12.1 \mu \mathrm{m})$ (Figure 5D). Type III-1 seeds were observed in L. virginicum; these showed a slightly raised anticlinal cell wall and a strongly convex periclinal cell wall with wide papillae $(24.6-36.5 \mu \mathrm{m}$ in diameter; average $=30.3 \mu \mathrm{m})$ (Figure 5L).

\subsection{Identification Key Based on Seed Morphology and Micromorphology}

Based on our morphological and micromorphological analysis of Lepidii seu Descurainiae Semen and adulterant seeds, we designed a key to accurately identify seeds. According to this key, seeds are identified according to shape, cross-sectional shape, appearance, mucilage reaction, wing-like appendage, and combining micromorphological characteristics, such as ornamentation, epidermal cell pattern, and shape of the anticlinal and periclinal cell walls, as described below:

1. Seeds ovoid, obovate-to-oblong in shape; linear-elliptic to linear-triangular in cross-section; dull.

2. Seeds $0.57-0.86 \times 0.32-0.55 \mathrm{~mm} ;$ no mucilage reaction; simple reticulate ornamentation; concave, smooth periclinal cell wall

Draba nemorosa

2. Seeds $1.25-2.21 \times 0.56-1.48 \mathrm{~mm}$; moderate mucilage reaction; reticulate-papillate ornamentation; coarse folded central papillae on periclinal cell wall.

3. Seeds $1.25-1.67 \times 0.56-1.00 \mathrm{~mm}$; wing-like appendage absent or narrow; nearly indistinct and convex anticlinal cell wall; narrow papillae $(9.4-16.0 \mu \mathrm{m}$ in diameter)

Lepidium apetalum

3. Seeds $1.65-2.21 \times 0.92-1.48 \mathrm{~mm}$; wing-like appendage wide; slightly raised and strongly convex anticlinal cell wall; wide papillae $(24.6-36.5 \mu \mathrm{m}$ in diameter)

Lepidium virginicum 
1. Seeds oblong or obliquely oblong-to-obovate pyriform in shape; not linear-elliptic in cross-section; somewhat shiny.

4. Seeds circular-to-elliptic in cross-section; weak mucilage reaction; simple reticulate ornamentation; smooth periclinal cell wall

Descurainia sophia

4. Seeds triangular-to-trapezoid in cross-section; no mucilage reaction; reticulate-tuberculate ornamentation; globular central tuberculae on periclinal cell wall.

5. Seeds obliquely oblong-to-obovate, pyriform in shape, circular or ovate in cross-section; slightly raised and convex anticlinal cell wall; narrow tuberculae $\quad(5.0-9.2 \mu \mathrm{m}$ in diameter)

\section{Erysimum cheiranthoides}

5. Seeds oblong in shape, triangular-to-trapezoid in cross-section; raised and strongly convex anticlinal cell wall; wide tuberculae $(9.1-17.2 \mu \mathrm{m}$ in diameter)

Erysimum macilentum

\section{Discussion}

We conducted a microscopic investigation of the morphology (shape, outline, color, size, wing-like appendage, and mucilage reaction) and micromorphology (ornamentation type, epidermal cell pattern, and anticlinal and periclinal cell walls) of the traditional herbal medicine Lepidii seu Descurainiae Semen and adulterant seeds. Using the results of microscopic analysis, we developed a morphological and micromorphological identification key that distinguishes authentic seed medicines from adulterants.

\subsection{Morphological Characteristics of Seeds}

Lepidii seu Descurainiae Semen is minute seeds that are difficult to distinguish from adulterant seeds by the naked eye. In this study, we used a stereomicroscope to examine the shape, size, and color of these seeds to enable accurate identification. The cross-sectional shape and presence of grooves were particularly informative and enabled differentiation between authentic Lepidii seu Descurainiae Semen and adulterant seeds.

According to the dispensatory on the visual and organoleptic examination of herbal medicines, seeds of Dr. nemorosa, which are adulterants of Lepidii seu Descurainiae Semen, are flat and ovoid [15]. In this study, seeds of Dr. nemorosa were easily distinguished from those of other species based on their linear-elliptic cross-sectional shape alone (Figure 2C). Additionally, seeds of Dr. nemorosa were the smallest (Figure 3) and lightest among all six species studied (Table 2). The morphologically similar seeds of E. cheiranthoides and E. macilentum were distinguishable from Lepidii seu Descurainiae Semen based on their shape (obliquely oblong-to-obovate, pyriform; Figure 1D) and cross-sectional shape (triangular-to-trapezoid; Figure 2E), respectively. Although the seeds of L. virginicum and L. apetalum, which are close relatives, were highly similar, they could be distinguished by their size (Figure 1B vs. Figures $1 \mathrm{~F}$ and 3 ), weight (Table 2), and the degree of development of the wing-like appendage (Figure 2B vs. Figure 2F). In the flora in China, Cheo et al. [36] characterized L. apetalum seeds as "wingless" and L. virginicum seeds as "narrowly winged, at least distally". However, we observed L. apetalum seeds with a narrow wing-like appendage. Thus, further ontogenetic studies are necessary to evaluate the embryological origin and the definition of the wing-like appendage in these species.

\subsection{Mucilage Reaction}

The mucilage reaction of fruits and/or seeds of higher plants upon hydration is used to identify plants at the species level [20-27]. Mucilage is reported frequently in the plant families Lamiaceae 
(Labiatae) [20], Brassicaceae (Cruciferae) [21,23,25], and Asteraceae (Compositae) [24]. The mucilage reaction has been used to differentiate Cuscuta chinensis Lamark and C. australis R. Br. (Convolvulaceae), which are authentic sources of Cuscutae Semen $[3,4]$ from C. japonica Choisy. Cuscutae Semen produces mucilage upon hydration, whereas $C$. japonica seeds show no mucilage reaction [17]. The degree of mucilage reaction has been used to distinguish between Plantago asiatica L. and P. depressa Willd. (Plantaginaceae) of Plantaginis Semen [18]. Here, mucilage was observed in the seeds of De. sophia and L. apetalum, which are authentic sources of Lepidii seu Descurainiae Semen; however, seeds of their adulterants showed no mucilage reaction. These data suggest that the mucilage reaction upon hydration is a convenient and useful method for the accurate identification of minute seed herbal medicines. Seeds of L. virginicum, which are morphologically similar to those of L. apetalum, also showed a mucilage reaction that was similar to that of L. apetalum seeds. Plant mucilage has received significant attention due to its pharmacological and therapeutic value [37-39]. Therefore, further analysis of the ingredients and pharmacological effects of mucilage in L. virginicum are needed to evaluate the potential of using L. virginicum as a medicinal substitute for L. apetalum.

\subsection{Micromorphological Characteristics}

Analysis of the micromorphological features of seeds using a scanning electron microscope revealed that Lepidii seu Descurainiae Semen—De. sophia (type I-1) and L. apetalum (type III-1)—are easily distinguishable from the seeds of adulterant species. These micromorphological characteristics of the seed surface are informative and useful for the identification of plant species at inter- and/or infra-species level [28-34]. The shape of the anticlinal cell wall boundaries and the periclinal cell wall were particularly useful for distinguishing authentic seed medicines from closely related species.

\section{Conclusions}

This is the first comprehensive study of Lepidii seu Descurainiae Semen and adulterant seeds in order to accurately identify seeds. The shape, cross-sectional shape, size, mucilage reaction, and surface pattern of the seed are useful for identifying and authenticating the studied species. Overall, the data presented suggest that microscopic analysis of seed morphology is a convenient and economical method for identifying seeds. We demonstrated that the investigation of morphological and micromorphological characteristics using microscopic imaging techniques is instrumental for discrimination between authentic herbal medicines and their adulterants.

Author Contributions: Conceptualization, J.-H.S. and S.Y.; methodology, J.-H.S. and G.C.; software, J.-H.S. and S.Y.; validation, S.Y.; formal analysis, J.-H.S. and S.Y.; investigation, J.-H.S. and G.C.; resources, B.C.M., G.C., and S.Y.; data curation, J.-H.S. and S.Y.; writing-original draft preparation, J.-H.S.; writing-review and editing, B.C.M. and S.Y.; visualization, J.-H.S.; supervision, B.C.M. and S.Y.; project administration, G.C.; funding acquisition, G.C.

Funding: This work was supported by the Discovery and Conservation of Medicinal Herb Resources from the Korea Institute of Oriental Medicine (grant number K18401).

Acknowledgments: We thank the Classification and Identification Committee of the KIOM for critical identification and the Korean Herbarium of Standard Herbal Resources (KIOM) for providing plant materials.

Conflicts of Interest: The authors declare that there are no conflicts of interest.

\section{References}

1. Korea Institute of Oriental Medicine. Defining Dictionary for Medicinal Herbs. 2018. Available online: http:/ / boncho.kiom.re.kr/codex (accessed on 4 April 2018).

2. Yang, S.; Kim, W.J.; Choi, G.; Yeo, S.M.; Moon, B.C. Morphological authentication studies on the original plants of Lepidii seu Descurainiae Semen. Korean Herb. Med. Inf. 2016, 4, $27-35$.

3. Chinese Pharmacopoeia Commission. Pharmacopoeia of the People's Republic of China; Medical Science and Technology Press: Beijing, China, 2015; ISBN 978-7506789295. 
4. Committee on Chinese Medicine and Pharmacy. Taiwan Herbal Pharmacopeia, 2nd ed.; English Version; Ministry of Health and Welfare: Taipei, Taiwan, 2013; pp. 155-156.

5. Hou, J.P.; Jin, Y. The Healing Power of Chinese Herbs and Medicinal Recipes; The Haworth Integrative Healing Press: New York, NY, USA, 2005; pp. 376-378, ISBN 978-0789022028.

6. Park, J.C.; Choi, G. Review on herbal medicinal materials in the Korean Pharmacopoeia and the Korean Herbal Pharmacopoeia. Korean Herb. Med. Inf. 2016, 4, 9-35.

7. Pharmacopoeia Committee of the DPRK. Pharmacopoeia of Democratic People's Republic of Korea, 7th ed.; Medicine and Science Press: Pyeongyang, Korea, 2011.

8. Smith, F.P.; Stuart, G.A. Chinese Medicinal Herbs; Georgetown Press: San Francisco, CA, USA, 1973.

9. Choopani, R.; Ghourchian, A.; Hajimehdipoor, H.; Kamalinejad, M.; Ghourchian, F. Effect of Descurainia sophia (L.) Webb ex Prantl on adult functional constipation: A prospective pilot study. J. Evid. Based Complement. Altern. Med. 2017, 22, 646-651. [CrossRef] [PubMed]

10. Chu, K.; Xu, W.; Li, H.; Chen, L.; Zhang, Y.; Tang, X. Extraction of Lepidium apetalum seed oil using supercritical carbon dioxide and anti-oxidant activity of the extracted oil. Molecules 2011, 16, 10029-10045. [PubMed]

11. Nimrouzi, M.; Zarshenas, M.M. Phytochemical and pharmacological aspects of Descurainia sophia Webb ex Prantl: Modern and traditional applications. Avicenna J. Phytomed. 2016, 6, 266-272. [PubMed]

12. Zhou, N.; Sun, Y.P.; Zheng, X.K.; Wang, Q.H.; Yang, Y.Y.; Bai, Z.Y.; Kuang, H.X.; Feng, W.S. A metabolomicsbased strategy for the mechanism exploration of traditional Chinese medicine: Descurainia sophia seeds extract and fractions as a case study. J. Evid. Based Complement. Altern. Med. 2017, 2017, 2845173. [CrossRef] [PubMed]

13. Choi, G. List of Fake Korean Medicinal Herbs; Korea Institute of Oriental Medicine: Daejeon, Korea, 2016; p. 75, ISBN 978-89-5970-249-7.

14. Korea Food and Drug Administration (KFDA). Coloured Illustrations for Discrimination of Herbal Medicine; Homibooks: Daejeon, Korea, 2009; pp. 196-197.

15. National Institute of Food and Drug Safety Evaluation. The Dispensatory on the Visual and Organoleptic Examination of Herbal Medicine; National Institute of Food and Drug Safety Evaluation: Cheongwon, Korea, 2012; pp. 552-553.

16. Moon, B.C.; Kim, W.J.; Yang, S.; Park, I.; Yeo, S.M.; Noh, P. Molecular authentication of Lepidii seu Descurainiae Semen by the development of mat $\mathrm{K}$ amplification primers and analysis of sequences. Korean J. Herbol. 2018, 33, 25-35.

17. Ji, C.Y.; Kim, T.J.; Lee, S.H.; Kim, Y.S.; Lee, G.S.; Kim, J.H.; Choi, G.; Ju, Y.S. Identification of morphological appearance of fine seed herbs using stereoscope (Report I)-Celosiae Semen, Celoisae Cristatae Semen, Cuscutae Semen, Perillae Semen. J. Korean Med. 2013, 34, 1-12. [CrossRef]

18. Kim, Y.S.; Ju, Y.S. Identification of morphological appearance of minute seed herbs using stereoscope (Report II)-Alli Tuberosi Semen, Alli Fistulosi Semen, Malvae Semen, Abutili Semen, Plantaginis Semen, Schizonepetae Semen. Korean J. Herbol. 2016, 31, 61-66. [CrossRef]

19. Van der Valk, J.M.A.; Leon, C.J.; Nesbitt, M. Macroscopic authentication of Chinese materia medica (CMM): A UK market study of seeds and fruits. J. Herb. Med. 2017, 8, 40-51. [CrossRef]

20. Ryding, O. Myxocarpy in the Nepetoideae (Lamiaceae) with notes on myxodiaspory in general. Syst. Geogr. Plants 2001, 71, 503-514. [CrossRef]

21. Appel, O.; Al-Shehbaz, I.A. Generic limits and taxonomy of Hornungia, Pritzelago, and Hymenolobus (Brassicaceae). Novon 1997, 7, 338-340. [CrossRef]

22. Beier, B.A.; Chase, M.; Thulin, M. Phylogenetic relationships and taxonomy of subfamily Zygophylloideae (Zygophyllaceae) based on molecular and morphological data. Plant Syst. Evol. 2003, 240, 11-39. [CrossRef]

23. Karaismailoğlu, M.C. Seed mucilage contents in some taxa of Aubrieta Adans. genus (Brassicaceae) and their systematic importance. Turk. J. Life Sci. 2017, 2, 145-148.

24. Kreitschitz, A.; Vallés, J. Achene morphology and slime structure in some taxa of Artemisia L. and Neopallasia L. (Asteraceae). Flora 2007, 202, 570-580. [CrossRef]

25. Vaughan, J.G.; Whitehouse, J.M. Seed structure and the taxonomy of the Cruciferae. Bot. J. Linn. Soc. 1971, 64, 383-409. [CrossRef]

26. Western, T.L. The sticky tale of seed coat mucilages: Production, genetics, and role in seed germination and dispersal. Seed Sci. Res. 2012, 22, 1-25. [CrossRef]

27. Young, J.A.; Evans, R.A. Mucilaginous seed coats. Weed Sci. 1973, 21, $2-54$. 
28. Barreto, L.C.; Echternacht, L.; Garcia, Q.S. Seed coat sculpture in Comanthera (Eriocaulaceae) and its implications on taxonomy and phylogenetics. Plant Syst. Evol. 2013, 299, 1461-1469. [CrossRef]

29. Barthlott, W. Epidermal and seed surface characters of plants: Systematic applicability and some evolutionary aspects. Nord. J. Bot. 1981, 1, 345-355. [CrossRef]

30. Bona, M. Seed-coat microsculpturing of Turkish Lepidium (Brassicaceae) and its systematic application. Turk. J. Bot. 2013, 37, 662-668. [CrossRef]

31. Khalik, K.A.; Van der Maesen, L.J.G. Seed morphology of some tribes of Brassicaceae (implications for taxonomy and species identification for the flora of Egypt). Blumea 2002, 47, 363-383.

32. Koul, K.K.; Nagpal, R.; Raina, S.N. Seed coat microsculpturing in Brassica and allied Genera (Subtribes Brassicinae, Raphaninae, Moricandiinae). Ann. Bot. 2000, 86, 385-397. [CrossRef]

33. Lu, L.U.; Fritsch, P.W.; Bush, C.M.; Dong, L.N.; Wang, H.; Li, D.Z. Systematic implications of seed coat diversity in Gaultherieae (Ericaceae). Bot. J. Linn. Soc. 2010, 162, 477-495. [CrossRef]

34. Song, J.H.; Kim, J.M.; Ok, M.K.; Hong, S.P. Comparative seed morphology of the tribe Alsineae (Caryophyllaceae) in Korea and its taxonomic implications. Korean J. Plant Taxon. 2015, 45, 369-379. [CrossRef]

35. Wickham, H. ggplot2: Elegant Graphics for Data Analysis; Springer: New York, NY, USA, 2009.

36. Cheo, T.Y.; Lou, L.I.; Yang, G.; Al-Shehbaz, I.A. Lepidium Linnaeus (Brassicaceae). In Flora of China; Wu, Z.Y., Raven, P.H., Eds.; Science Press and Missouri Botanical Garden Press: St. Louis, CA, USA; Beijing, China, 2001; Volume 8, pp. 28-33.

37. Malviya, R.; Srivastava, P.; Kulkarni, G.T. Applications of mucilages in drug delivery-A review. Adv. Biol. Res. 2011, 5, 1-7.

38. Prajapati, V.D.; Jani, G.K.; Moradiya, N.G.; Randeria, N.P. Pharmaceutical applications of various natural gums, mucilages and their modified forms. Carbohydr. Polym. 2013, 92, 1685-1699. [CrossRef] [PubMed]

39. Wadhwa, J.; Nair, A.; Kumria, R. Potential of plant mucilages in pharmaceuticals and therapy. Curr. Drug. Deliv. 2013, 10, 198-207. [CrossRef] [PubMed]

(C) 2018 by the authors. Licensee MDPI, Basel, Switzerland. This article is an open access article distributed under the terms and conditions of the Creative Commons Attribution (CC BY) license (http:/ / creativecommons.org/licenses/by/4.0/). 